\title{
Relationships of Copper Concentrations between the Different Soft Tissues of Telescopium telescopium and the Surface Sediments Collected from Tropical Intertidal Areas
}

\author{
Chee Kong YAP ${ }^{1}$, Noorhaidah ARIFIN ${ }^{1} \&$ Soo Guan TAN $^{2}$ \\ ${ }^{1}$ Department of Biology, Faculty of Science, Universiti Putra Malaysia, Serdang, Selangor, Malaysia \\ ${ }^{2}$ Department of Cell and Molecular Biology, Faculty of Biotechnology and Biomolecular Science, Universiti \\ Putra Malaysia, Serdang, Selangor, Malaysia \\ Correspondence: Chee Kong YAP, Department of Biology, Faculty of Science, Universiti Putra Malaysia, 43400 \\ UPM, Serdang, Selangor, Malaysia. Tel: 60-3-8946-6616. E-mail: yapckong@hotmail.com
}

Received: June 18, 2012 Accepted: July 2, 2012 Online Published: January 13, 2013

doi:10.5539/ijc.v5n1p8 URL: http://dx.doi.org/10.5539/ijc.v5n1p8

\begin{abstract}
In this paper, the relationships of $\mathrm{Cu}$ concentrations between the snail's different soft tissues and surface sediments were evaluated by using multivariate analysis, namely cluster analysis, correlation analysis and stepwise multiple linear regression analysis. Three findings can be highlighted based on the present study. First, different concentrations of $\mathrm{Cu}$ were found in the different soft tissues, indicating different mechanisms of sequestration and regulations of $\mathrm{Cu}$ in these different tissues. By comparing the $\mathrm{Cu}$ concentrations in similar tissues, spatial variations of $\mathrm{Cu}$ were found in the different sampling sites although there was no consistent pattern of $\mathrm{Cu}$ in these sampling sites. Second, the digestive caecum was a better biomonitoring organ for $\mathrm{Cu}$ contamination. Third, higher $\mathrm{Cu}$ contamination might not necessarily result in higher $\mathrm{Cu}$ bioavailability to $T$. telescopium based on the cluster analysis. In general, all the different soft tissues could be used as biomonitoring tissues of $\mathrm{Cu}$ bioavailabilities and contamination in Malaysian intertidal mudflats provided they were statistically analyzed by using a multivariate approach. To our knowledge, this is the most comprehensive study of $\mathrm{Cu}$ accumulation in the different soft tissues of T. telescopium from tropical intertidal area in relation to sediment data.
\end{abstract}

Keywords: Telescopium telescopium, $\mathrm{Cu}$ distribution, different soft tissues, biomonitor

\section{Introduction}

Every metal has a different behavior due to different abundance from natural sources and rate of anthropogenic input. In this study, copper $(\mathrm{Cu})$ was focused upon because 1) $\mathrm{Cu}$ is one of the major and popular metal pollutants in this region and especially in Malaysia, 2) $\mathrm{Cu}$ is essential for the successful growth and development of many species of aquatic organisms, but its rate and extent of accumulation and retention are modified by numerous biological and biotic variables. $\mathrm{Cu}$ is an essential trace element in the snail's biology and it normally accumulates and stores $\mathrm{Cu}$ for use in the synthesis of hemocyanin which is a respiratory pigment (Gundacker, 2000). However, anthropogenic $\mathrm{Cu}$ could potentially raise the amount of $\mathrm{Cu}$ accumulated in the snail's tissues, 3) $\mathrm{Cu}$ is among the most toxic heavy metals in the marine biota (Eisler, 2000) and it is often accumulated and causes irreversible harm to some species at concentrations just above the level required for growth and reproduction.

Nowadays that the use of molluscs as biomonitors of trace metal bioavailabilities in the coastal waters is widely accepted (Rainbow, 1995; 1997; Yap et al., 2007; 2009). Most molluscs are potential biomonitors since they fulfill most of the criteria for being good biomonitors because they are sedentary, abundant, of relative longevity, large, easily collected and weighed (Rainbow, 1997; Rainbow \& Phillips, 1993). Gastropods, being small and relatively immobile organisms, are good models for examining the effects of pollution on populations because they are in contact with the polluted bottom sediments, have short generation times, and their fitness are easy to assess (Peerzada et al., 1990; Jones et al., 2000; Lefcort et al., 2004; Ismail \& Safahieh, 2004; Dang et al., 2005; Yap \& Noorhaidah, 2008; Yap et al., 2008; 2009).

Nonetheless, most of the biomonitoring studies are based on the total soft tissues of gastropods, due to perhaps 
difficulties in separating the different soft tissues. Once there is an egg spawning in the mollusks, the metal contents in the individual will be drastically changed. The metal data based on the total soft tissues is therefore always subjected to much arguments and a question on whether the metal data would truly reflect metal bioavailabilities could be raised. Even though efforts to reduce such discrepancies such as sampling within a short period of time or sampling at the end of spawning if this season was known could be done, such sampling techniques were very much dependent on costs, manpower, facilities, weather and even luck. One of the methods to increase the validity of metal data to reflect the metal bioavailabilities of the sampling site is the use of different soft tissues in the biomonitors (Yap et al., 2004; 2006a; 2006b). Yap et al. (2006b) used the different soft tissues of Perna viridis to indicate the bioavailabilities and contamination of heavy metals in the semi-enclosed Straits of Johore potentially receiving anthropogenic sources. Furthermore, knowledge on the distribution of metals in isolated organs/tissues of marine organisms is useful for the identification of specific organs that may tend to accumulate higher levels of heavy metals (Szefer et al., 2002).

The snail Telescopium telescopium (Family: Potamididae) is an herbivorous and detritus feeder. They feeds on organic detritus and surface algae found on exposed mudflats (Nair \& Saraswathy, 1971). Earlier, Yap et al. (2009) suggested T. telescopium as a potential biomonitor of $\mathrm{Cu}$ bioavailabilities and contamination in tropical intertidal areas but more evidence is needed to prove its usefulness as a biomonitor for $\mathrm{Cu}$. This paper enhances the importance of biomonitoring work in Malaysia by extending the number of different mollusks species to be used as biomonitors, since the benchmark for the heavy metal biomonitoring study is well established based on Perna viridis. This paper follows up that earlier biomonitoring work, aiming to study the spatial variation of $\mathrm{Cu}$ bioavailabilities to intertidal mudflat snail $T$. telescopium collected from Peninsular Malaysia which were dissected into seven different soft tissues, in relation to $\mathrm{Cu}$ levels in surface sediments.

\section{Materials and Methods}

Mudflat snails and surface sediments were collected from 16 geographical sites along the intertidal areas of Peninsular Malaysia (Table 1), between April 2005 and September 2006. The descriptions for all sampling sites are given in Table 1. These samples were brought back to the laboratory for metal analysis.

About 6-21 individuals of T. telescopium of relatively similar shell heights (Table 1) from each population were thawed at room temperature $\left(27-29^{\circ} \mathrm{C}\right.$ ) on a clean tissue paper, washed and rinsed with distilled water (to remove adhering particles and other contaminants). Later, they were dissected and pooled into seven different soft tissues, namely foot, cephalic tentacle (CT), mantle, muscle, gill, digestive caecum (DC) and remaining soft tissues (REST). In this study, the gut contents (including DC) of the snails are not depurated after collection because of 1) easy contamination during gut depuration and 2) the big size and weights of the snails are difficult to do the depuration processes. Thus, the depuration process is not practical.

All of the snail and sediment samples were dried at $80{ }^{\circ} \mathrm{C}$ for $72 \mathrm{~h}$ until constant dry weights. For the snail samples, three replicates of each different part of soft tissues of snails were digested in concentrated nitric acid (AnalaR grade; BDH 69\%). For the sediments, the dried sediment samples were crushed by using a mortar and pestle and sieved through a $63 \mu \mathrm{m}$ aperture stainless steel sieve and were then shaken vigorously to produce homogeneity. For the analyses of total $\mathrm{Cu}$ concentrations in the sediment samples, three replicates were analyzed by using the direct aqua-regia method (Yap et al., 2002a; 2003). About $1 \mathrm{~g}$ of each dried sample was digested in a combination of concentrated $\mathrm{HNO} 3$ (AnalaR grade; $\mathrm{BDH} 69 \%$ ) and $\mathrm{HClO} 4$ (AnalaR grade; $\mathrm{BDH} 60 \%$ ) in the ratio of $4: 1$. The snail and sediment samples were put into a hot-block digester first at low temperature $\left(40{ }^{\circ} \mathrm{C}\right)$ for 1 hour and then were fully digested at $140^{\circ} \mathrm{C}$ for at least 3 hours (Yap et al., 2002a; 2003). 
Table 1. Sampling sites, sampling dates, shell heights (mean \pm standard error, $\mathrm{cm}$ ) of Telescopium telescopium and site descriptions in the intertidal areas of Peninsular Malaysia. $\mathrm{N}=$ number of individuals analyzed

\begin{tabular}{|c|c|c|c|c|c|}
\hline No. & Sampling sites & Date & $\mathrm{N}$ & Shell height & Sites description \\
\hline 1 & $\begin{array}{l}\text { Kg Pasir Puteh (KPPuteh), } \\
\text { Johore [N } 01^{\circ} 26 \text { '05.8”; } \\
\text { E 10156'02.4”] }\end{array}$ & 30 Apr 2006 & 11 & $8.6 \pm 0.11$ & $\begin{array}{l}\text { Fishing area, mangrove and } \\
\text { industrial area at Pasir Gudang }\end{array}$ \\
\hline 2 & $\begin{array}{c}\text { Pantai Punggur (PPunggur), } \\
\text { Johore [N } 01^{\circ} 41^{\prime} 07.2 ; \\
\left.\text { E } 103^{\circ} 05^{\prime} 54.6^{\prime \prime}\right]\end{array}$ & 29 Apr 2006 & 8 & $7.3 \pm 0.18$ & A recreational area \\
\hline 3 & $\begin{array}{c}\text { Kuala Sg Ayam (KSAyam), } \\
\text { Johore [N } 01^{\circ} 45^{\prime} 12.5^{\prime \prime} ; \\
\left.\text { E } 102^{\circ} 55^{\prime} 45.4\right]\end{array}$ & 29 Apr 2006 & 11 & $6.58 \pm 0.14$ & $\begin{array}{l}\text { A recreational beach and a muddy } \\
\text { area }\end{array}$ \\
\hline 4 & $\begin{array}{c}\text { Sg. Balang Laut (SBLaut), } \\
\text { Johore [N } 01^{\circ} 52^{\prime} 21.0 ” ; \text { E } \\
\left.102^{\circ} 44^{\prime} 16.5^{\prime \prime}\right]\end{array}$ & 29 Apr 2006 & 15 & $5.65 \pm 0.15$ & $\begin{array}{c}\text { A busy jetty, housing area, fishing } \\
\text { village, mangrove swamp and an } \\
\text { estuary }\end{array}$ \\
\hline 5 & $\begin{array}{c}\text { Kuala Lukut Kecil } \\
\text { (KLukutK), Negeri Sembilan } \\
{\left[\mathrm{N} 02^{\circ} 33^{\prime} \text { 42.2"; E } 101^{\circ} 48^{\prime}\right.} \\
\left.00.2^{\prime \prime}\right]\end{array}$ & 28 Apr 2006 & 17 & $5.35 \pm 0.07$ & $\begin{array}{l}\text { A prawn aquaculture, mangrove } \\
\text { swamp, water irrigation }\end{array}$ \\
\hline 6 & $\begin{array}{c}\text { Kuala Lukut Besar } \\
\text { (KLukutB), Negeri Sembilan } \\
{\left[\mathrm{N} 02^{\circ} 34^{\prime} \text { 49.2"; E } 101^{\circ} 49^{\prime}\right.} \\
\left.34.4^{\prime \prime}\right]\end{array}$ & 28 Apr 2006 & 6 & $8.98 \pm 0.13$ & $\begin{array}{l}\text { A jetty under construction, } \\
\text { mangrove swamp and near a prawn } \\
\text { farm }\end{array}$ \\
\hline 7 & $\begin{array}{l}\text { Sg Sepang Kecil (SepangK), } \\
\text { Selangor [N 02 } 36^{\circ} 4.11^{\prime \prime} \\
\left.\text { E } 101^{\circ} 41^{\prime} 7.79^{\prime \prime}\right]\end{array}$ & 18 Aug 2006 & 9 & $4.96 \pm 0.06$ & $\begin{array}{l}\text { Aquaculture of prawn and muddy } \\
\text { area }\end{array}$ \\
\hline 8 & $\begin{array}{l}\text { Bagan Lalang (BLalang), } \\
\text { Selangor [N 02 } 355^{\prime} 57.52^{\prime} \text {; } \\
\left.\text { E } 101^{\circ} 42^{\prime} 31.41^{\prime \prime}\right]\end{array}$ & 15 Sep 2006 & 10 & $8.35 \pm 0.08$ & $\begin{array}{c}\text { Aquaculture of prawn, water gate } \\
\text { and near a dragon fruit farm and } \\
\text { muddy area }\end{array}$ \\
\hline 9 & $\begin{array}{l}\text { Sg Sepang Besar (SepangB), } \\
\text { Selangor [N02 } 36^{\circ} 19.41^{\prime \prime} ; \\
\left.\text { E } 101^{\circ} 42^{\prime} 11.51^{\prime \prime}\right]\end{array}$ & 7 Jan 2006 & 12 & $7.81 \pm 0.12$ & $\begin{array}{c}\text { A restaurant, jetty and water } \\
\text { irrigation. }\end{array}$ \\
\hline 10 & $\begin{array}{l}\text { Sg Janggut (SJanggut), } \\
\text { Selangor [N 03 } 10^{\prime} 20.0^{\prime \prime} ; \\
\left.\text { E } 101^{\circ} 18^{\prime} 1.4^{\prime \prime}\right]\end{array}$ & 20 Mar 2006 & 10 & $8.41 \pm 0.17$ & $\begin{array}{l}\text { A housing area, muddy, chicken } \\
\text { farm, palm oil plantation and } \\
\text { prawn culture activities }\end{array}$ \\
\hline 11 & $\begin{array}{l}\text { Kg Pantai Jeram (KPJeram), } \\
\text { Selangor [N 03 } 13 \text { ' } 14.6^{\prime \prime} ; \\
\left.\text { E } 101^{\circ} 18^{\prime} 19.5^{\prime \prime}\right]\end{array}$ & 24 Feb 2006 & 10 & $7.64 \pm 0.06$ & A jetty and sea-food restaurant \\
\hline 12 & $\begin{array}{c}\text { Pulau Indah (PIndah), } \\
\text { Selangor [N 03 0’ 22.94”; } \\
\left.\text { E } 101^{\circ} 18^{\prime} 22.5^{\prime \prime}\right]\end{array}$ & 16 Aug 2006 & 21 & $8.74 \pm 0.16$ & $\begin{array}{c}\text { Irrigation water, a small jetty and } \\
\text { muddy area }\end{array}$ \\
\hline 13 & $\begin{array}{c}\text { Jambatan Permaisuri Bainun } \\
\text { (JPBainum), Perak [N 04 } 16^{\circ} \\
\left.\text { 46.0”; E } 100^{\circ} 39^{\prime} 50.2^{\prime \prime}\right]\end{array}$ & 27 Feb 2006 & 13 & $7.15 \pm 0.13$ & $\begin{array}{l}\text { A residential area, recreational area } \\
\text { (kayak) and an estuary. }\end{array}$ \\
\hline 14 & $\begin{array}{c}\text { Kg Deralik (KDeralik), Perak } \\
\text { [N 04 14' 53.8”; E } 100^{\circ} 42^{\prime} \\
\left.09.1^{\prime \prime}\right]\end{array}$ & 25 Feb 2006 & 8 & $9.2 \pm 0.08$ & $\begin{array}{l}\text { Busy traffic and road to west port } \\
\text { of Klang }\end{array}$ \\
\hline 15 & $\begin{array}{c}\text { Kg Setiawan (KSetiawan), } \\
\text { Perak [N 04 14' 44.3”; } \\
\left.\text { E } 100^{\circ} 41^{\prime} 35.6^{\prime \prime}\right]\end{array}$ & 25 Feb 2006 & 6 & $7.83 \pm 0.07$ & $\begin{array}{c}\text { A residential area, mangrove (very } \\
\text { muddy) with no direct pollution } \\
\text { observed }\end{array}$ \\
\hline 16 & $\begin{array}{c}\text { Jetty Kuala Juru (KJuru), } \\
\text { Penang [N 05²0.410'; E } \\
\left.100^{\circ} 24^{\prime} 51.8^{\prime}\right] \\
\end{array}$ & 20 Apr 2005 & 20 & $8.96 \pm 0.99$ & An industrial area in Penang \\
\hline
\end{tabular}


The analytical procedures of the four geochemical fractions of the surface sediments followed the Sequential Extraction Technique (SET) described by Badri and Aston (1983) with a slight modification by Yap et al. (2002a). These four fractions, extraction solutions and the conditions employed on each of the fraction were:

(1) easily, freely, leachable or exchangeable (EFLE): About $10 \mathrm{~g}$ of the sample was shaken continuously with 50 $\mathrm{mL}$ of $1.0 \mathrm{~mol} \mathrm{~L}-1$ ammonium acetate $\left(\mathrm{NH}_{4} \mathrm{CH}_{3} \mathrm{COO}\right)$, at $\mathrm{pH} 7.0$ and at room temperature $\mathrm{pH} 7.0$ for 3 hours.

(2) Acid-reducible (AR): The residue from the first step was shaken continuously with $50 \mathrm{~mL}$ of $0.25 \mathrm{~mol} \mathrm{~L}^{-1} \mathrm{M}$ hydroxylammonium chloride $\left(\mathrm{NH}_{2} \mathrm{OH} \cdot \mathrm{HCl}\right)$ that had been acidified with $\mathrm{HCl}$ to $\mathrm{pH} 2$, at room temperature for 3 hours.

(3) Oxidisable-organic (OO): The residue from the second step was first oxidized with $30 \% \mathrm{H}_{2} \mathrm{O}_{2}$ in a water bath at $90-95{ }^{\circ} \mathrm{C}$. After being oxidized, the residue was shaken continuously with $50 \mathrm{ml}$ of $1.0 \mathrm{~mol} \mathrm{~L}^{-1}$ ammonium acetate $\left(\mathrm{NH}_{4} \mathrm{CH}_{3} \mathrm{COO}\right)$ that had been acidified with $\mathrm{HCl}$ to $\mathrm{pH} 2$, at room temperature for 3 hours.

(4) Resistant (Res): The residue from the third step was digested similarly as described previously for total $\mathrm{Cu}$ determination in sediments.

For each fraction, the resulting solution obtained at the end of each step was filtered through a Whatman No. 1 filter paper (diameter: $110 \mathrm{~mm}$; Schleicher and Schuell, Whatman International Ltd, Maidstone, England) into a clean, acid-washed polyethylene bottle. The residue was then washed with $20 \mathrm{~mL}$ of double distilled water and filtered through a Whatman No. 1 filter paper (same as above) into the same polyethylene bottle. The filtrate was stored until metal determination. The residue used for each step was first dried and weighed before the next step was carried out. At each step of the SET, a blank was done using an identical procedure to ensure that the samples and chemicals used were not contaminated with metals (Yap et al. 2002a). The nonresistant (NR) fraction was calculated based on the summation of EFLE, AR and OO while total summation (SUM) was the summation of EFLE, AR, OO, and Res.

The concentrations of the $\mathrm{Cu}$ in the filtrates of both the snails and the sediments were determined using an air-acetylene flame atomic absorption spectrophotometer (FAAS) Perkin-Elmer Model AAnalyst 800. The data were presented in $\mathrm{mg} \mathrm{kg}^{-1}$ dry weight basis. Multiple-level calibration standards were analyzed to generate calibration curves against which the sample concentrations could be calculated. Standard solution of $\mathrm{Cu}$ was prepared from $1000 \mathrm{mg} \mathrm{Cu} \mathrm{L}^{-1}$ stock solution (MERCK Titrisol).

To avoid possible contamination, all the glassware and plastic materials used were acid-washed in $10 \%$ concentrations of $\mathrm{HNO}_{3}$ (AnalaR grade; BDH 69\%) to minimize external contamination. Procedural blanks and quality control samples made from standard solutions with each $1000 \mathrm{ppm}$ stock solution for $\mathrm{Cu}$ were analyzed once every five samples in order to check for sample accuracy (Yap et al., 2006a). The quality of the methods used were checked with Certified Reference Materials for Marine sediment-MESS-3, National Research Council Canada [certified $\mathrm{Cu}$ value: $33.9 \mathrm{mg} \mathrm{kg}^{-1} \mathrm{dw}$, measured $\mathrm{Cu}$ value: $31.6 \mathrm{mg} \mathrm{kg}^{-1} \mathrm{dw}$; recovery $=93.2 \%$ ] while for tissues of snails were verified using Dogfish Liver (DOLT-3, National Research Council Canada) [certified $\mathrm{Cu}$ value: $31.2 \mathrm{mg} \mathrm{kg}^{-1} \mathrm{dw}$, measured $\mathrm{Cu}$ value: $32.1 \mathrm{mg} \mathrm{kg}^{-1} \mathrm{dw}$; recovery= $101.7 \%$ ]. The detection limits of the FAAS for $\mathrm{Cu}$ was $0.01 \mathrm{mg} \mathrm{L}^{-1}$. 

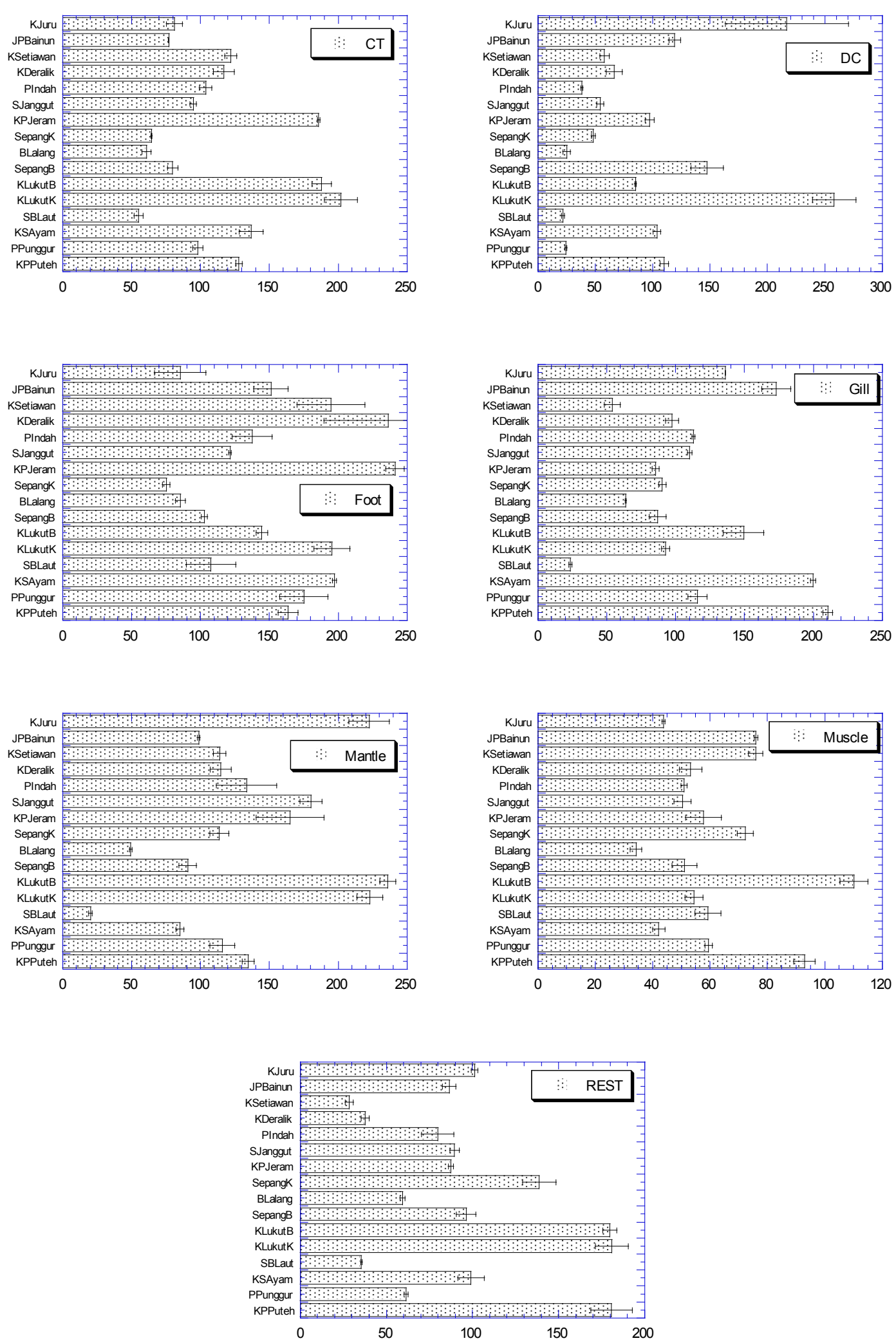

Figure 1. $\mathrm{Cu}$ concentrations (mean \pm standard error, $\mathrm{mg} \mathrm{kg}^{-1}$ dry weight) in the different soft tissues of Telescopium telescopium collected from 16 sampling sites in Peninsular Malaysia. (Y-axis= sampling sites; $\mathrm{x}$-axis $=\mathrm{Cu}$ concentrations) 
For statistical analysis, the relationships of $\mathrm{Cu}$ concentrations between the different parts in the snails and geochemical factions in the sediments were elucidated by using Pearson's correlation coefficients and stepwise multiple linear regression analysis (SMLRA) and cluster analysis. All the multivariate analyses were performed by using the Statistical Program for Social Science (SPSS) for Windows, version 15.0 software, except for the cluster analysis. The cluster analysis which was based on Single Linkage Euclidean distances, on the $\mathrm{Cu}$ concentrations in the four geochemical fractions and the non-resistant fractions for the surface sediments collected from 16 sampling sites, was done by using the STATISTICA 99" Edition (Version 5.5) software. All the data for the three multivariate analyses were $\lg ($ mean +1$)$ transformed in order to reduce the variance (Zar, 1996). The general purpose of the SMLRA is to find the most influential independent or predictor variables (represented by the $\mathrm{Cu}$ concentrations in the geochemical fractions in the sediment) that could influence the dependent or criterion variables (represented by $\mathrm{Cu}$ concentrations in the different soft tissues).

\section{Results}

The $\mathrm{Cu}$ concentrations in the different soft tissues of $T$. telescopium collected from 16 sampling sites are presented in Figure 1 and the overall $\mathrm{Cu}$ concentrations are given in Table 2. The highest $\mathrm{Cu}$ concentrations (mg $\mathrm{kg}^{-1}$ dry weight) were consistently found in gill (210) and REST (180) from KPPuteh population while the KLukutK population had the highest $\mathrm{Cu}$ levels in CT (202) and DC (258). The highest Cu levels in mantle (235) and muscle (110) were found in the KLukutB population while KPJeram had the highest $\mathrm{Cu}$ level in the foot (241).

Table 2. Overall $\mathrm{Cu}$ concentrations ( $\mathrm{mg} \mathrm{kg}^{-1}$ dry weight) in the different soft tissues of Telescopium telescopium collected from 16 sampling sites in Peninsular Malaysia

\begin{tabular}{lccccc}
\hline & Minimum & Maximum & Max/Min & Mean & Std Error \\
\hline CT & 55 & 202 & 3.7 & 112 & 11.6 \\
DC & 22 & 258 & 11.8 & 92 & 17.0 \\
Foot & 75 & 241 & 3.2 & 151 & 13.2 \\
Gill & 23 & 210 & 8.9 & 113 & 12.8 \\
Mantle & 20 & 235 & 11.6 & 131 & 15.3 \\
Muscle & 34 & 110 & 3.2 & 62 & 4.9 \\
REST & 28 & 180 & 6.4 & 96 & 12.6 \\
\hline
\end{tabular}

Note: CT-Cephalic tentacle; REST-remaining soft tissues; DC-digestive caecum.

From Table 2, ratios of maximum to the minimum values are useful to understand which tissue has the highest $\mathrm{Cu}$ variation. It was found that DC and mantle had the higher ratio (> 11), followed by gill, REST and other tissues $(<4)$. The $\mathrm{Cu}$ concentrations of the four geochemical fractions of surface sediments in the snail habitats from 16 sampling sites are given in Table 3. It was found that KLukutK recorded the highest $\mathrm{Cu}$ levels of EFLE, OO, Res, SUM and NR. The highest AR was found in SBLaut. The sampling sites at KPPuteh, KLukutK, SepangK, KPJeram and JPBainun recorded the dominance (> 50\%) of the nonresistant fraction of $\mathrm{Cu}$, based on the $\mathrm{NR} / \mathrm{R}$ ratio.

Based on the dendrogram using cluster analysis on the geochemical fractions of the surface sediments (Figure 2i), it was found that KPPuteh ranked on the top and it subclustered with KJuru. Similarly, based on the dendrogram using cluster analysis on seven tissues of T. telescopium (Figure 2ii), KPPuteh was also found to be ranked on the top but it subclustered with KLukutB (not KJuru). The correlation coefficients of $\mathrm{Cu}$ concentrations between the different soft tissues of the snails and the geochemical fraction of the surface sediment are presented in Table 4. It is clearly seen that the only significant $(\mathrm{P}<0.05)$ pairwises were found for DC-OO, DC-Res, DC-SUM, and DC-NR. Based on the SMLRA presented in Table 5, only two tissues namely DC and mantle were significantly $(\mathrm{P}<0.05)$ influenced by EFLE, AR, OO, Res, and NR. 
Table 3. Mean $\mathrm{Cu}$ concentrations ( $\mathrm{mg} \mathrm{kg}^{-1}$ dry weight) of four geochemical fractions in the surface sediments collected from 16 intertidal sampling sites of Peninsular Malaysia $(\mathrm{N}=3)$

\begin{tabular}{ccccccccc}
\hline No. & Sites & EFLE & AR & OO & Res & SUM & NR & NR/Res \\
\hline 1 & KPPuteh & 0.64 & 0.36 & 22.76 & 10.14 & 33.9 & 23.76 & 2.34 \\
2 & PPunggur & 0.48 & 0.40 & 1.31 & 6.91 & 9.1 & 2.19 & 0.32 \\
3 & KSAyam & 0.70 & 0.38 & 6.13 & 34.41 & 41.62 & 7.21 & 0.21 \\
4 & SBLaut & 0.71 & 0.63 & 1.15 & 10.66 & 13.15 & 2.49 & 0.23 \\
5 & KLukutK & 1.77 & 0.57 & 158.32 & 81.02 & 241.68 & 160.66 & 1.98 \\
6 & KLukutB & 0.53 & 0.52 & 3.65 & 7.12 & 11.82 & 4.7 & 0.66 \\
7 & SepangK & 0.11 & 0.06 & 39.55 & 22.83 & 62.55 & 39.72 & 1.74 \\
8 & BLalang & 0.44 & 0.60 & 1.27 & 5.80 & 8.11 & 2.31 & 0.40 \\
9 & SepangB & 0.14 & 0.39 & 2.41 & 4.17 & 7.11 & 2.94 & 0.71 \\
10 & SJanggut & 0.41 & 0.27 & 1.96 & 5.81 & 8.45 & 2.64 & 0.45 \\
11 & KPJeram & 0.30 & 0.31 & 1.34 & 1.60 & 3.55 & 1.95 & 1.22 \\
12 & PIndah & 0.10 & 0.39 & 0.96 & 4.07 & 5.52 & 1.45 & 0.36 \\
13 & JPBainum & 0.47 & 0.37 & 9.09 & 1.08 & 11.01 & 9.93 & 9.19 \\
14 & KDeralik & 0.46 & 0.60 & 3.61 & 7.55 & 12.22 & 4.67 & 0.62 \\
15 & KSetiawan & 0.43 & 0.52 & 1.59 & 7.57 & 10.11 & 2.54 & 0.34 \\
16 & Kuala Juru & 0.52 & 0.14 & 18.6 & 26.27 & 45.53 & 19.26 & 0.73 \\
\hline
\end{tabular}

Note: EFLE-easily, freely, leachable or exchangeable; AR-acid-reducible; OO-oxidisable-organic; Res-resistant; NR-nonresistant (summation of EFLE, AR, OO); SUM-summation of EFLE, AR, OO and Res.

Table 4. Pearson's correlation coefficients of $\mathrm{Cu}$ concentrations (based on $\log 10[$ mean +1$]$ ) between the different soft tissues of Telescopium telescopium and the geochemical fraction of the surface sediment. $\mathrm{N}=16$

\begin{tabular}{|c|c|c|c|c|c|c|}
\hline & EFLE & AR & $\mathrm{OO}$ & Res & SUM & NR \\
\hline CT & 0.46 & 0.03 & 0.39 & 0.24 & 0.33 & 0.37 \\
\hline DC & 0.36 & -0.44 & 0.79 & 0.60 & 0.73 & 0.77 \\
\hline Foot & 0.39 & 0.17 & 0.13 & 0.00 & 0.12 & 0.13 \\
\hline Gill & -0.02 & -0.34 & 0.22 & 0.10 & 0.16 & 0.18 \\
\hline Mantle & 0.08 & -0.35 & 0.37 & 0.07 & 0.18 & 0.33 \\
\hline Muscle & 0.02 & 0.24 & -0.01 & -0.15 & -0.10 & -0.02 \\
\hline REST & 0.19 & -0.25 & 0.45 & 0.39 & 0.40 & 0.43 \\
\hline
\end{tabular}

Note: EFLE-easily, freely, leachable or exchangeable; AR-acid-reducible; OO-oxidisable-organic; Res-resistant; SUM-summations of four geochemical fractions; NR-nonresistant; CT-Cephalic tentacle; REST-remaining soft tissues; DC-digestive caecum. Values in bold are significant at $\mathrm{P}<0.05$. 
(i) Tree Diagram for 16 Cases

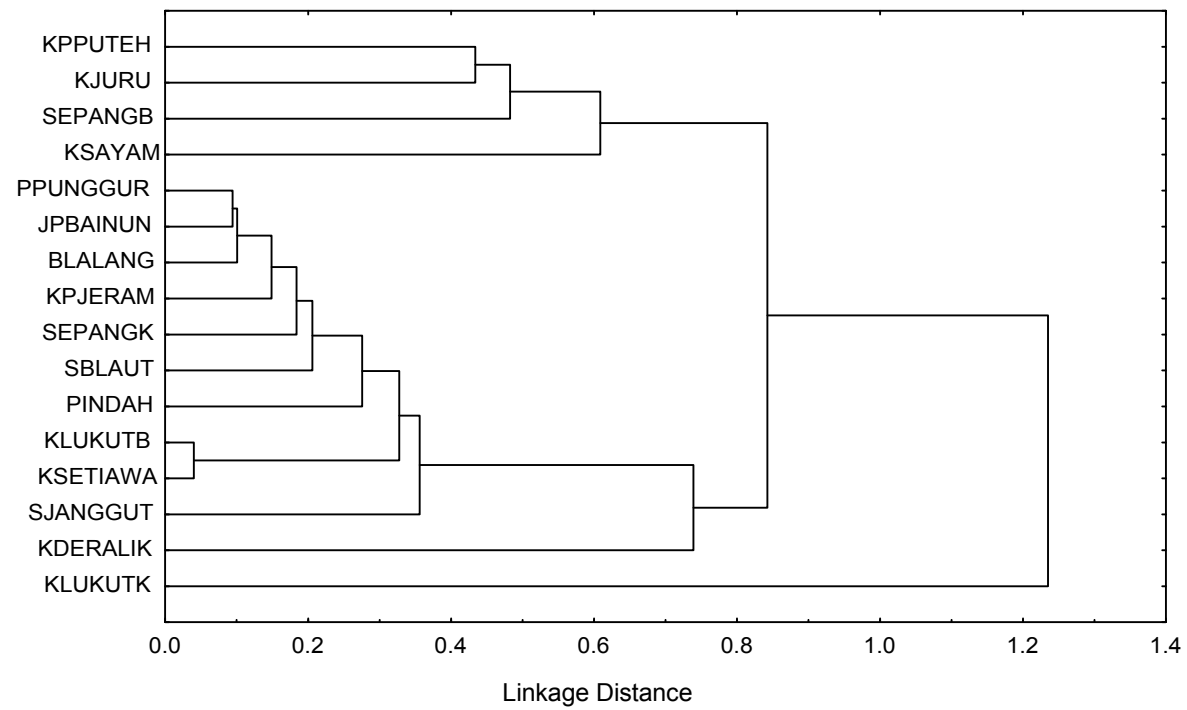

(ii) Tree Diagram for 16 Cases

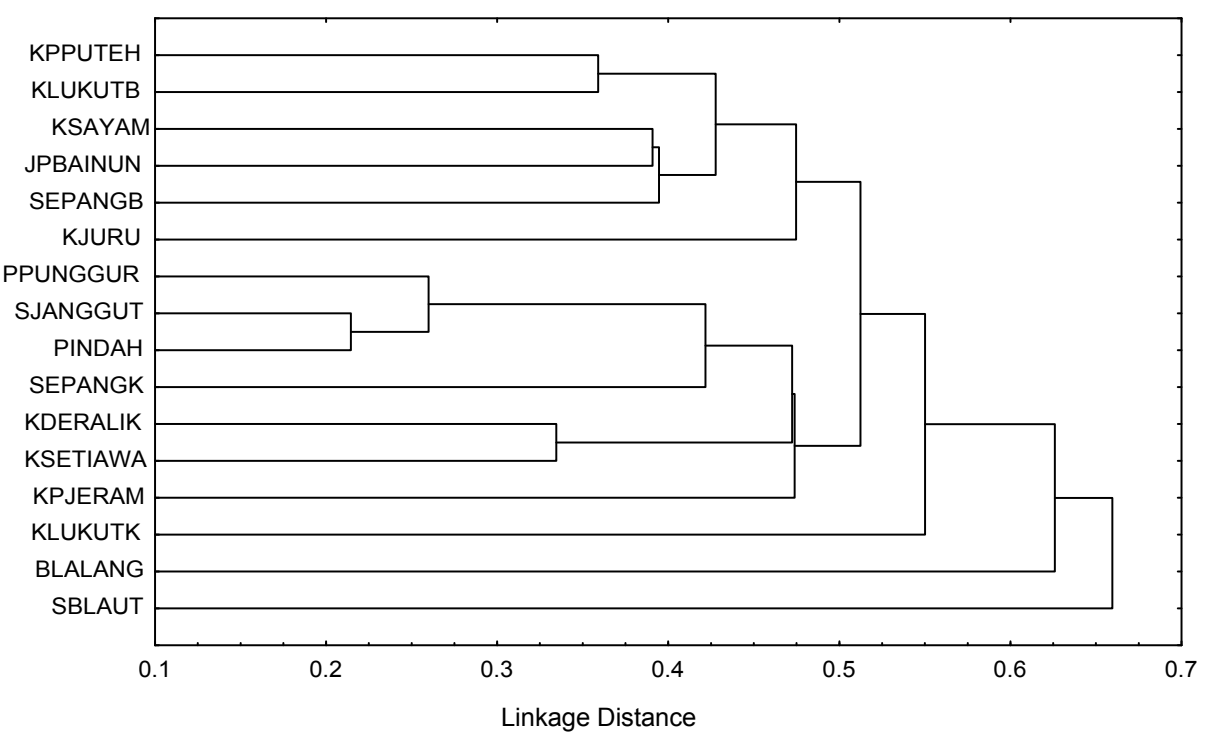

Figure 2. Cluster analysis based on Single Linkage Euclidean distances, (i) on the geochemical fractions of $\mathrm{Cu}$ (EFLE, acid-reducible, oxidisable-organic, resistant and nonresistant) and their summation in the surface sediments, and (ii) on the $\mathrm{Cu}$ concentrations in seven tissues of Telescopium telescopium collected from 16 sampling sites. All the cluster analyses were based on $\log _{10}($ mean +1$)$ transformed data 
Table 5. Stepwise multiple linear regression analysis of $\mathrm{Cu}$ concentrations (based on $\log 10[$ mean +1$]$ ) between the different soft tissues of Telescopium telescopium and the geochemical fractions of sediment. $\mathrm{N}=16$

\begin{tabular}{|c|c|c|c|}
\hline Tissue & Multiple linear stepwise regression equation & $\mathrm{R}$ & $\mathrm{R}^{2}$ \\
\hline $\mathrm{CT}=$ & No significant variable was selected. & - & - \\
\hline $\mathrm{DC}=$ & $0.492+0.473(\mathrm{EFLE})-0.543(\mathrm{AR})+1.990(\mathrm{OO})+0.130(\mathrm{Res})-2.099(\mathrm{NR})$ & 0.87 & 0.76 \\
\hline Foot $=$ & No significant variable was selected. & - & - \\
\hline Gill $=$ & No significant variable was selected. & - & - \\
\hline Mantle $=$ & $0.645+0.592(\mathrm{EFLE})-0.213(\mathrm{AR})+3.096(\mathrm{OO})-0.004(\mathrm{Res})-3.529(\mathrm{NR})$ & 0.79 & 0.64 \\
\hline Muscle $=$ & No significant variable was selected. & - & - \\
\hline $\mathrm{REST}=$ & No significant variable was selected. & - & - \\
\hline
\end{tabular}

Note: EFLE-easily, freely, leachable or exchangeable; AR-acid-reducible; OO-oxidisable-organic; Res-resistant; SUM-summations of four geochemical fractions; NR-nonresistant; CT-Cephalic tentacle; REST-remaining soft tissues; DC-digestive caecum. Those dependent variables were significantly $(\mathrm{P}<0.05)$ influenced by the selected independent variables.

\section{Discussion}

\subsection{Different Concentrations of $\mathrm{Cu}$ Were Found in the Different Soft Tissues}

As expected, different concentrations of $\mathrm{Cu}$ were found in the different soft tissues (Figure 1, Table 2), indicating different mechanisms of sequestration and regulations of $\mathrm{Cu}$ in these different tissues. The major reason why the maximum levels are found in different tissues in the different sampling stations could be attributed to a lot of biotic and abiotic factors which are unknown and need investigations. The consistent high/highest levels of $\mathrm{Cu}$ are not found in most tissues of a particular sampling site. This makes the interpretation on the results hard to explain. It was found that the accumulation pattern for $\mathrm{Cu}$ was as follows: Foot $>$ mantle $>$ gill $>\mathrm{CT}>\mathrm{REST}>$ DC $>$ muscle (Table 2). Based on Table 2, the different ratios of maximum to minimum $\mathrm{Cu}$ concentrations in the different soft tissues also provide evidence to prove that the accumulative capacity for $\mathrm{Cu}$ was different in each and every tissue. All the ratios ranged from 3.2-11.8 with foot and muscle having the narrowest range while DC and mantle had the widest range.

The different degrees of $\mathrm{Cu}$ accumulation might also indicate that the mechanism of detoxification and metallothionein synthesis for this essential metal was different from one tissue to another (Viarengo et al., 1985). By comparing the $\mathrm{Cu}$ concentrations in similar tissues (Figure 1), spatial variation of $\mathrm{Cu}$ was found in the different sampling sites although there was no consistent pattern of $\mathrm{Cu}$ in these sampling sites. However, the well reported metal-polluted site from KPPuteh was found to have distinctly high $\mathrm{Cu}$ bioavailability to T. telescopium if it was based on gills, muscle and REST, although KPPuteh was not as polluted as KLukutK and SepangK based on total concentrations (SUM) of $\mathrm{Cu}$ in the surface sediments (Table 3).

Based on Figure 1, there is no consistent pattern of tissue which always accumulated high concentration of $\mathrm{Cu}$ from any population. For example, only 4 out of 16 geographical populations accumulated highest concentrations of $\mathrm{Cu}$ in the gills. This suggested that gill was not necessarily the main target organ for $\mathrm{Cu}$ accumulation although some reported studies did mention elevated concentrations of metals in the gills of some molluscs (Gundacker, 2000; Yap et al., 2006c).

The different $\mathrm{Cu}$ levels found in the different soft tissues could be due to various mechanisms which included homeostatic processes in the body of the snail in response to varying metabolic demands and entrapment of $\mathrm{Cu}$ under certain conditions by additional mucilage production/extrusion by the snails (Dallinger, 1993). Gastropods need $\mathrm{Cu}$ as an essential constituent for their respiratory pigment hemocyanin (Gundacker, 2000). Such differences in $\mathrm{Cu}$ accumulation in the different soft tissues may be explained by different regulation capacities for this essential metal.

\subsection{Digestive Caecum Is a Better Biomonitoring Organ for Cu Contamination}

Based on the correlation analysis presented in Table 4, only DC was significantly and positively correlated with OO, Res, SUM and NR (R-values ranging from 0.60-0.79). The correlation coefficients close to zero or negative indicated that the concentrations of $\mathrm{Cu}$ geochemical fractions was not directly reflected in other soft tissues of $T$. telescopium. When the correlation results (Table 4) were compared to those of SMLRA (Table 5), it was found 
that the DC was significantly $(\mathrm{P}<0.05)$ influenced by EFLE, AR, OO, Res, and NR based on SMLRA result. Thus, the SMLRA result complemented the significant correlation results for OO, Res and NR. Both correlation and SMLRA results highly supported that $\mathrm{DC}$ is a better biomonitoring organ for $\mathrm{Cu}$ contamination.

In addition, mantle was also significantly $(\mathrm{P}<0.05)$ influenced by the same independent variables. The SMLRA result could also explain the high variations of $\mathrm{Cu}$ concentrations in DC and mantle (indicated by the high ratios of maximum to minimum, Table 2 ) in response to environmental $\mathrm{Cu}$ bioavailability since they were significantly influenced by the geochemical fractions in the surface sediments.

By using the presented model based on SMLRA, it was noticed that all the DC of T. telescopium could reflect the environmental contamination by $\mathrm{Cu}$ levels as represented by surface sediments. Hence, it could be used as the best biomonitoring organ for $\mathrm{Cu}$ contamination in the sampling site. The positive correlation coefficient of DC indicated that the higher the $\mathrm{Cu}$ concentration in the geochemical fractions in the sediment, the higher the metal concentrations in the $\mathrm{DC}$ could be expected. The amount of $\mathrm{Cu}$ accumulated in sediments and the form or ligands with which the $\mathrm{Cu}$ was associated could influence bioavailability to the biota and the potential of dissolution (Jones et al., 2008). The distribution or fractionation of sediment-associated metals, such as $\mathrm{Cu}$, among various sediment fractions regulated both mobility and availability (Ankley et al., 1993). Therefore, the $\mathrm{Cu}$ levels found in the different geochemical fractions would likely have influenced the bioaccumulation in the DC and mantle of $T$. telescopium. Since the snail populations in this study were not depurated to clear the gut content, the positive correlation of $\mathrm{Cu}$ between DC and sediment is expected and therefore, it does not indicate a bioaccumulation but just the contamination with food.

Earlier, Yap and Noorhaidah (2011) reported that gill and digestive caecum of T. telescopium as biomonitors of $\mathrm{Pb}$ bioavailability and contamination by $\mathrm{Pb}$. Following that, Yap et al. (2011) suggested the use of different soft tissues of T. telescopium as potential biomonitoring tissues of $\mathrm{Zn}$ bioavailability. One similarity with that reported by Yap and Noorhaidah (2011) and Yap et al. (2011) was that the digestive caecum was also found as a better biomonitoring organ for $\mathrm{Cu}$ contamination. Thus, the present finding complemented that digestive caecum of $T$. telescopium was a better biomonitoring tissues for $\mathrm{Pb}, \mathrm{Zn}$ and $\mathrm{Cu}$.

\subsection{Higher Cu Contamination Might Not Necessarily Mean Higher Cu Bioavailabilities to T. Telescopium}

The cluster analysis based on $\mathrm{Cu}$ concentrations in all seven tissues of T. telescopium collected from 16 sampling sites (Figure 2ii), showed that a higher bioavailiability of $\mathrm{Cu}$ was found in the KPPuteh and KLukutB populations. The higher $\mathrm{Cu}$ contamination and bioavailability to the KPPuteh population was almost expected as indicated by a number of previously reported studies (Yap et al., 2002a; 2003; 2009). However, the contamination by $\mathrm{Cu}$ based on NR/Res ratios $(>1)$ are not evidently shown for KLukutB (only for KPPuteh). Although KLukutK, SepangK, KPJeram and JPBainum are also found to have NR/Res > 1 (Table 3) (indicating the contribution of $\mathrm{Cu}$ in the sediments were mainly originated from anthropogenic sources), they do not cluster with KPPuteh. This could be due to other factors which need further studies.

The highest $\mathrm{Cu}$ levels were found at KLukutK based on EFLE, OO, Res, SUM, and NR in the sediments which could explain why KLukutK had the highest levels of $\mathrm{Cu}$ in $\mathrm{CT}$ and DC of T. telescopium. However, this phenomenon was not clearly exhibited in the dendrograms in Figure 2. This could be due to the fact that only two tissues out of seven in T. telescopium collected from KLukutK showed the highest levels of $\mathrm{Cu}$. Another metal-contaminated site at KJuru (Yap et al., 2002a; 2003; 2009), which was found to have higher Cu levels in the sediments also did not exhibit a distinctively higher $\mathrm{Cu}$ bioavailability in $T$. telescopium. The $\mathrm{Cu}$ bioavailability at the $\mathrm{Cu}$-contaminated site at KJuru seemed to be controlled by other physico-chemical factors that potentially affected the $\mathrm{Cu}$ speciation. Consequently, higher $\mathrm{Cu}$ bioavailability to the biomonitor $T$. telescopium was not obtained. Therefore, the present findings indicated that a higher $\mathrm{Cu}$ contamination might not necessarily result in higher $\mathrm{Cu}$ bioavailabilities to T. telescopium which agreed with those found based on intertidal snails (Telescopium telescopium and Nerita lineata) from an unknown and no anthropogenic site, by direct observation (Yap, 2010).

There are a lot of complicated biological and environmental factors that could influence the $\mathrm{Cu}$ bioavailabilities to the different soft tissues of the snails. Biological variables affecting $\mathrm{Cu}$ accumulations in marine organisms include the organism's age, size (Catsiki et al., 1994) and developmental stage, physiological and genetic adaptations to high $\mathrm{Cu}$ substrates, inherent species differences and tissue specificity, such as gill and osphradium of gastropods (Eisler, 1979). The genetic structures of these snail populations of different geographical sites should be determined in future studies so as to increase the validity of T. telescopium as a good biomonitor (Yap et al., 2002b; Yap \& Tan, 2011). 


\section{Conclusion}

To conclude all the above points, it was found that out of the seven investigated soft tissues of T. telescopium, $\mathrm{DC}$ was the best biomonitoring organ of $\mathrm{Cu}$ contamination, in relation to $\mathrm{Cu}$ levels in surface sediments, in tropical intertidal mudflats. The multivariate analysis such as cluster analysis and SMLRA based on all different soft tissues of the snails had proven to be useful in identifying the best organ for the biomonitoring of $\mathrm{Cu}$. However, in order to confirm T. telescopium as a valid biomonitor, future studies focusing on genetic and physiological changes due to metal pollution are much needed.

\section{Acknowledgements}

The authors wish to acknowledge the financial support provided through the Research University Grant Scheme (RUGS), [Vote no.: 9316800], by Universiti Putra Malaysia.

\section{References}

Ankley, G. T., Matison, V. R., \& Leonard, E. N. (1993). Predict the acute toxicity in freshwater sediments: evaluation of the role of acid volatile sulfide. Environmental and Toxicological Chemistry, 12, 315-320. http://dx.doi.org/10.1002/etc.5620120214

Badri, M. A., \& Aston, S. R. (1983). Observation on heavy metal geochemical associations in polluted and non-polluted estuarine sediments. Environmental Pollution, 6(Series B), 181-193.

Catsiki, V. A., Bei, F., \& Nicolaidou, A. (1994). Size dependent metal concentrations in two marine gastropod species. Netherland Journal of Aquatic Ecology, 28(2), 157-165. http://dx.doi.org/10.1007/BF02333986

Dallinger, R. (1993). Strategies of metal detoxification in terrestrial invertebrates. In R. Dallinger, \& P. S. Rainbow (Eds.), Ecotoxicology of metals in invertebrates (pp. 245-289). Boca Raton: Lewis Publishers.

Dang, T. C., Stephane, B., Oliver, W., Subramaniam, K., Kae, S. W., Sivasothi, N., \& Jeffrey. P. O. (2005). Heavy metal contamination in mangrove habitats of Singapore. Marine Pollution Bulletin, 50, 1713-1744.

Eisler, R. (1979). Copper accumulations in coastal and marine biota. In J. O. Nriagu (Ed.), Copper in the environment Part 1: Ecological Cycling (pp. 383-449). New York: Wiley.

Eisler, R. (2000). Handbook of Chemical Risk Assessment: Health Hazards to Human, Plants, Animals. Vol. 1 (Metals). Boca Raton: Lewis Publisher.

Gundacker, C. (2000). Comparison of heavy metal bioaccumulation in freshwater molluscs of urban river habitats in Vienna. Environmental Pollution, 110, 61-71. http://dx.doi.org/10.1016/S0269-7491(99)00286-9

Ismail, A., \& Safahieh, A. (2004). Copper and zinc in intertidal surface sediment and Telescopium telescopium from Lukut River, Malaysia. Coastal Marine Science, 29(2), 111-115.

Jones, G. B., Mercurio, P., \& Olivier, F. (2000). Zinc in fish, crabs, oysters and mangrove flora and fauna from Cleveland Bay. Marine Pollution Bulletin, 41, 345-352. http://dx.doi.org/10.1016/S0025-326X(00)00132-6.

Jones, R. P., Hassan, S. M., \& Rodgers Jr., J. H. (2008). Influence of contact duration on sediment-associated copper fractionation and bioavailability. Ecotoxicology and Environmental Safety, 71(1), 104-116. http://dx.doi.org/10.1016/j.ecoenv.2007.09.004

Lefcort, H. D., Abbott, P., Cleary, D. A., Howell, E., Keller, N. C., \& Smith. M. M. (2004). Aquatic snails from mining sites have evolved to detect and avoid heavy metals. Arch. Environmental Contamination and Toxicology, 46, 478-484. http://dx.doi.org/10.1007/s00244-003-3029-2

Nair, N. N., \& Saraswathy, M. (1971). The biology of wood-boring teredinid molluscs. Marine Biology, 9, 335-509. http://dx.doi.org/10.1016/S0065-2881(08)60345-4.

Peerzada, N., Eastbrook, C., \& Guinea, M. (1990). Heavy metal concentration in Telescopium from Darwin

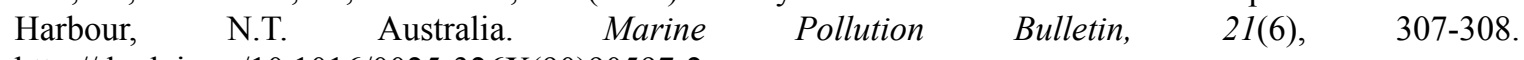
http://dx.doi.org/10.1016/0025-326X(90)90597-2

Rainbow, P. S. (1995). Biomonitoring of heavy metal availability in the marine environment. Marine Pollution Bulletin, 31(4-12), 183-192.

Rainbow, P. S. (1997). Trace metal accumulation in marine invertebrates: marine biology or marine chemistry? Journal of Marine Biological Association of UK, 77, 195-210. http://dx.doi.org/10.1017/S0025315400033877

Rainbow, P. S., \& Phillips, D. J. H. (1993). Cosmopolitan biomonitors of trace metals. Marine Pollution Bulletin, 26(11), 595-601. http://dx.doi.org/10.1016/0025-326X(93)90497-8 
Szefer, P., Frelek, K., Szefer, K., Lee, C. B., Kim, B. S., Warzocha, J., ... Ciesielski, T. (2002). Distribution and relationships of trace metals in soft tissue, byssus and shells of Mytilus edulis trossulus from the southern Baltic. Environmental Pollution, 120, 423-444. http://dx.doi.org/10.1016/S0269-7491(02)00111-2

Viarengo, A., Palmero, S., Zanicchi, G., Capelli, R., Vaissiere, R., \& Orunesu, M. (1985). Role of metallothioneins in $\mathrm{Cu}$ and $\mathrm{Cd}$ accumulation and elimination in the gill and digestive gland cells of Mytilus galloprovincialis Lam. Marine Environmental Research, 16, 23-36. http://dx.doi.org/10.1016/0141-1136(85)90018-2

Yap C. K., Noorhaidah, A., Azlan, A., Ismail, A., Siraj, S. S., \& Tan. S. G. (2009). Telescopium telescopium as potential biomonitors of $\mathrm{Cu}, \mathrm{Zn}$, and $\mathrm{Pb}$ for the tropical intertidal area. Ecotoxicology and Environmental Safety, 72, 496-506. http://dx.doi.org/10.1016/j.ecoenv.2007.12.005

Yap, C. K, Ismail, A., Tan, S. G., \& Ismail, A. R. (2004). Assessment of different soft tissues of the green-lipped mussel Perna viridis (Linnaeus) as biomonitoring agents of $\mathrm{Pb}$ : Field and laboratory studies. Water, Air and Soil Pollution, 153, 253-268. http://dx.doi.org/10.1023/B:WATE.0000019946.84885.94

Yap, C. K. (2010). High metal contamination and bioavailability might not be necessarily related to high human activity by direct observation: Evidence from metal data in sediments and intertidal snails collected from an unknown anthropogenic site in Malaysia. Asian Journal of Microbiology, Biotechnology and Environmental Sciences, 2(1), 1-5.

Yap, C. K., \& Noorhaidah, A. (2008). An evidence of $\mathrm{Pb}$ redistribution in the different soft tissues of Telescopium telescopium collected from a Pb-contaminated intertidal site. Asian Journal of Microbiology, Biotechnology and Environmental Sciences, 10(3), 463-468.

Yap, C. K., \& Noorhaidah, A. (2011). Gill and digestive caecum of Telescopium telescopium are biomonitors of $\mathrm{Pb}$ bioavailability and contamination by $\mathrm{Pb}$ in the tropical intertidal area. Sains Malaysiana, 40(10), 1075-1085.

Yap, C. K., \& Tan. S. G. (2011). Ecotoxicological genetic studies on the green-lipped mussel Perna viridis in Malaysia. In L. E. McGevin (Ed.), Mussels: Anatomy, Habitat and Environmental Impact (pp. 221-244). USA: Nova Science Publishers.

Yap, C. K., Fairuz, M. S., Nelson, C., Noorhaidah, A., \& Tan, S. G. (2008). Comparison of heavy metal concentrations in the different parts of Telescopium telescopium collected from a relatively less polluted site at Sungai Janggut and a polluted site at Kuala Juru. Malaysian Fishery Journal, 7(1), 41-46.

Yap, C. K., Ismail, A., \& Tan, S. G. (2003). Cd and Zn in the straits of Malacca and intertidal sediments of the west coast of Peninsular Malaysia. Marine Pollution Bulletin, 46, 1348-1353. http://dx.doi.org/10.1016/S0025-326X(03)00193-0

Yap, C. K., Ismail, A., Cheng, W. H., \& Tan. S. G. (2006a). Crystalline and tissue redistribution in Perna viridis as indiators of $\mathrm{Cu}$ and $\mathrm{Pb}$ bioavailabilities and contamination in coastal waters. Ecotoxicology and Environmental Safety, 63, 413-423. http://dx.doi.org/10.1016/j.ecoenv.2005.02.005

Yap, C. K., Ismail, A., Edward, E. B., Tan, S. G., \& Siraj, S. S. (2006b). Use of different soft tissues of Perna viridis as biomonitors of bioavailability and contamination by heavy metals $(\mathrm{Cd}, \mathrm{Cu}, \mathrm{Fe}, \mathrm{Pb}, \mathrm{Ni}$, and $\mathrm{Zn})$ in a semi-enclosed intertidal water, the Johore Straits. Toxicology and Environmental Chemistry, 88(1-4), 683-695. http://dx.doi.org/10.1080/02772240600874139

Yap, C. K., Ismail, A., Ismail, A. R., \& Tan, S. G. (2006c). Biomonitoring of ambient concentrations of Cd, Cu, $\mathrm{Pb}$ and $\mathrm{Zn}$ in the coastal wetland water by using gills of the green-lipped mussel Perna viridis. Wetland Science, 4(4), 247-252.

Yap, C. K., Ismail, A., Tan, S. G., \& Omar, H. (2002a). Concentrations of $\mathrm{Cu}$ and $\mathrm{Pb}$ in the offshore and intertidal sediments of the west coast of Peninsular Malaysia. Environment International, 28, 467-479. http://dx.doi.org/10.1016/S0160-4120(02)00073-9

Yap, C. K., Noorhaidah, A., \& Tan, S. G. (2011). Different soft tissues of Telescopium telescopium as potential biomonitoring tissues of Zn bioavailability in Malaysian intertidal mudflats. New York: Nova Science Publishers Inc.

Yap, C. K., Tan, S. G., Ismail, A., \& Omar, H. (2002b). Genetic variation of green-lipped mussel Perna viridis (Linnaeus) from the west coast of Peninsular Malaysia. Zoological Studies, 41(4), 376-387.

Zar, J. H. (1996). Biostatistical Analysis (3rd ed.). New Jersey: Prentice Hall. 